\title{
MARGARITA ISABEL O'BRIEN: \\ CONDESA JACOBITA Y DAMA DE LA MONARQUÍA ESPAÑOLA ${ }^{1}$
}

\author{
Naiara Pavía Dopazo \\ Universidad de La Rioja
}

\begin{abstract}
RESUMEN: Se traza aquí el perfil político de Margarita Isabel O’Brien, ejemplo de cortesana y espía en las cortes europeas de mediados del siglo XVIII, que sirvió a los intereses de la Monarquía hispánica, como agente de Ensenada y de Huéscar en París, y a los de la causa Estuardo, la sagrada causa jacobita, desde su matrimonio en 1726 con el conde de Lismore. Aceptada por Isabel de Farnesio en su corte, desempeñó el papel de dueña de honor de la reina. Su correspondencia con Don Fernando de Silva Álvarez de Toledo, duque de Huéscar, conservada en el Archivo de la Casa de Alba, es la fuente fundamental de este trabajo.
\end{abstract}

Palabras clave: Margarita Isabel O’Brien, Corte, espionaje, Ensenada, duque de Huéscar, jacobitas.

\section{MARGUERITA ELISABETH O'BRIEN: JACOBITE COUNTESS AND LADY OF THE SPANISH MONARCHY}

ABSTRACT: This paper sketches the politic profile of Margaret Elizabeth O'Brien, an example of courtesan and spy on the European royal courts of the middle 18th century, who served the interests of the Hispanic monarchy as an agent of Ensenada and Huéscar in Paris, and those of the Stuart cause, the sacred jacobite cause, since her marriage in 1726 with the count of Lismore. Accepted by Isabel Farnesio on her court, she played the role of Queen's courtesan. Her

1. Este trabajo se inserta en el proyecto de investigación HAR 2009-13824, del que es investigador principal José Luis Gómez Urdáñez, catedrático de Historia de la Universidad de La Rioja. 
correspondence with duke of Huéscar, preserved on the House of Alba archive, is the main source of this work.

Keywords: Margaret Elizabeth O'Brien, Court, espionage, diplomacy, Ensenada, duke of Huéscar, jacobites.

A medida que vamos conociendo más las redes políticas construidas en torno a las primeras figuras de la corte de los Borbones y su importancia para el logro de objetivos atribuidos a la gloria de sus respectivos "jefes" 2 , van apareciendo algunos personajes cuya vida y acción es bien distinta a la de los cortesanos y a la de los servidores políticos. Entre ellos, han despertado mucho interés los espías, los agentes en cualquier empresa secreta, sea de espionaje político, militar, o incluso científico y técnico ${ }^{3}$, pero se conocen mucho menos las vidas de mujeres que representaron papeles similares al lado de ministros o cortesanos de otros países, o de ministros rivales en el propio: mujeres con ideas políticas, objetivos bien definidos, leales al jefe ${ }^{4}$.

Los estudios recientes sobre las relaciones clientelares han sacado a la luz la importante presencia de los cargos reales en la configuración de redes políticas, así como el papel que jugaron sus miembros en las relaciones de poder que en

2. Para una visión de la época, véase GÓMEZ URDÁÑEZ, J.L., Fernando VI, Madrid, 2001; también El proyecto reformista de Ensenada, Lleida, 1996. Sobre la red política del marqués de la Ensenada véase GONZÁLEZ CAIZÁN, C., La red política del marqués de la Ensenada, Madrid, Fundación Jorge Juan, 2004.

3. Sobre el mundo de los espías en la Europa del XVIII destaca el pionero estudio del catedrático polaco Cesar Taracha, véase TARACHA, C., "El marqués de la Ensenada y los servicios secretos en la época española de Fernando VI", en: Brocar: Cuadernos de investigación histórica, no 25, 2001, págs. 109-122 y TARACHA, C., "Informes de los servicios de inteligencia españoles del siglo XVIII: contenido, estructura, formas de envío de la información secreta", en: Conferencia Internacional. En la paz como en la guerra. El espionaje como instrumento de la política de Estado, Lublín, 2010; así como su tesis doctoral recientemente traducida al español: Ojos y oídos de la Monarquía española. La organización del espionaje y la información secreta durante el siglo XVIII, Madrid, Ministerio de Defensa, 2011.

4. Sobre la importancia de las damas en el juego político, son de interés, por poner algunos ejemplos, los estudios recientes FRANCO RUBIO, G.A., "Espacios de sociabilidad, espacios de poder. Algunas reflexiones sobre la articulación de redes sociales en la España del siglo XVIII", en: MARTíNEZ RUÍZ, E., (Coord.), Vínculos y sociabilidades en España e Iberoamérica: siglos XVI y XIX, Madrid, Ediciones Puerto Llano 2005. págs. 59-110. LÓPEZCORDÓN CORTEZO, M.A., "Entre damas anda el juego. Las camareras mayores de Palacio en la edad moderna", en: Cuadernos de Historia Moderna. Anejos, no 2, 2003, (Ejemplar dedicado a: Monarquía y Corte en la España Moderna), págs. 123-152. En adelante, remitiremos a bibliografía específica de éstas y otras historiadoras sobre el tema. 
ellas se establecieron ${ }^{5}$. La transformación de la realidad institucional del Estado que llevó a cabo la dinastía Borbón, fue pareja a la de unas redes clientelares, formadas en torno a ella, cuyos miembros compartían unos intereses sociales, económicos y políticos, siempre en relación directa con los de los monarcas.

Así, desde la llegada de la dinastía Borbón, ganar lealtades y recompensar servicios fue la tónica que marcó los cambios en la organización de las casas reales y en la praxis del ceremonial. Desde que Felipe $V$ ocupara el trono sus cónyuges y sucesores buscaron en la Corte un entorno propio y fiable, como muy bien señala María Victoria López Cordón: "la Casa no era una cuestión personal sino institucional y por ello resultó imprescindible, que integrara al conjunto de súbditos fieles de la Monarquía, los de los territorios peninsulares, los de aquellos desgajados en Utrecht, o, a los que, procedentes de Francia e Irlanda, no habían dudado en prestarle su servicio" 6 . Los reyes y reinas de la casa Borbón se mostraron, desde el primer momento, poco dispuestos a someterse a los compromisos y equilibrios que estructuraban la vida cortesana y prefirieron utilizar el rígido y complicado ceremonial hispánico establecido por la Casa de Austria en su provecho.

Las soberanas siguieron la misma tendencia y trataron de asegurarse la fidelidad en su entorno inmediato, integrando en su propia Casa a miembros de las casas nobles de Castilla y a una parte de la "familia" de servidores de la reina predecesora. Pero sobre todo, buscaron usar el cargo real como su propia vía de clientelismo, es decir, quisieron contar con una corriente de opinión favorable a sus intereses y hacer explícito su poder como intermediarias. Con la nueva Mo-

5. Sobre el papel de la corte destacan la perspectiva conceptual y metodológica planteada y desarrollada por Pedro Luis Lorenzo Cadarso en su artículo LORENZO CADARSO, P.L., "Los grupos cortesanos. Propuestas teóricas", en: GÓMEZ URDÁÑEZ, J.L, y DELGADO BARRADO, J.L., Ministros de Fernando VI, Córdoba, Editorial de la Universidad de Córdoba, 2006. págs. 141-156. Y los enfoques más recientes de José María Imízcoz, donde destacan entre otros: IMÍZCOZ BEUNZA, J.M.,"Élites administrativas, redes cortesanas y captación de recursos en la construcción social del Estado Moderno", en: Trocadero: revista de historia moderna y contemporánea, nº 19, 2007, pág. 11-30, e IMÍZCOZ BEUNZA, J.M.,"Las redes sociales de las élites, conceptos, fuentes y aplicaciones", en: Las élites en la época moderna: la monarquía española, vol. 1, 2009, (Nuevas perspectivas), págs. 77-112. A los que hay que unir los interesantes estudios de Jean Pierre Dedieu, entre ellos: DEDIEU, J.P., "Amistad, familia, patria y rey", en: Melanges de la Casa de Velázquez, no 35, 2005, págs. 27-50 y DEDIEU, J.P, "Dinastía y élites de poder en el reinado de Felipe V", en: Los Borbones: dinastía y memoria de nación en la España del siglo XVIII, (Actas del coloquio internacional celebrado en Madrid, mayo de 2000), págs. 381-400.

6. LÓPEZ-CORDÓN CORTEZO, M.V., "Servicios y favores en la Casa de la Reina", en: ANDÚJAR del CASTILLO, F. y FELICES de la FUENTE, M.M., El poder del dinero. Ventas y honores en el Antiguo Régimen, Madrid, Biblioteca Nueva, 2011, págs. 223-247, pág. 230. Sobre los múltiples cargos reales ejercidos por mujeres en la Casa de la reina véase también LÓPEZ-CORDÓN CORTEZO, M.V., "La evolución de las damas entre los siglos XVII y XVIII", en: MARTÍNEZ MILLÁN, J. y MARÇAL LOURENÇO, M.P., (Coord.), Las relaciones discretas entre las Monarquías Hispana y Portuguesa: Las Casas de las Reinas (siglos XV-XIX), Vol. 2, 2009, págs. 1357-1398. 
narquía el papel de la "familia de mujeres" cambió su significación cortesana, que hasta entonces se limitaba, oficialmente, a servir y adecuar a las reinas en los usos propios de la etiqueta borgoñona. Pero al mismo tiempo se propiciaba su acción en la Corte, incluso en el terreno político, como demuestran las investigaciones recientes que han profundizado en el estudio de las formas de sociabilidad de la corte del siglo XVIII . En ellos se muestra la participación de las servidoras de la reina en la actividad pública de la Monarquía así como en otros aspectos de la vida cortesana, como fueron los salones y tertulias. Entre estos últimos destacó la academia del Buen Gusto, presidida por la condesa de Sarriá, madre de la duquesa de Lemos, camarera mayor de Bárbara de Braganza ${ }^{8}$. Unos espacios que otorgaban a las mujeres un lugar privilegiado en la "tertulia" o en la "conversación", donde estaba muy presente la cuestión política9. La capacidad de las damas fue reconocida incluso por algunos ilustrados contemporáneos como Feijoo, que en su Defensa de las mujeres, destaca su buen hacer en estas lides ${ }^{10}$.

No obstante, a medida que conocemos más sobre la vida cotidiana de las mujeres del siglo XVIII, tenemos una mayor perspectiva de análisis para descubrir su capacidad de influencia en el ámbito más privado de su vida doméstica y en sus relaciones familiares y de amistad ${ }^{11}$. Así podemos observar el papel político

7. Véase la pionera obra de FARGE, A. y DAVIS, Z., Historia de las mujeres en occidente. Vol. 3. Del Renacimiento a la llustración, Madrid, Taurus, 1992. Al que hay que unir recientes estudios sobre el papel de las mujeres en las formas de sociabilidad cortesana, entre los que destaca el de FRANCO RUBIO, G.A., "El salón parcialmente iluminado. Prejuicios, contradicciones y tópicos sobre las mujeres en los espacios de sociabilidad de la España ilustrada", en: CARZOLIO de ROSSI, M.I. y FERNÁNDEZ PRIETO, R.I., (Coords): El Antiguo Régimen: una mirada de dos mundos: España y América, Argentina, Prometeo Libros, 2010, págs. 151-174.

8. FRANCO RUBIO, G.A., "Bárbara de Braganza, la querella de las mujeres y la educación femenina", en: LÓPEZ-CORDÓN CORTEZO, M.V. y FRANCO RUBIO, G., (Coords.), Actas de la VIII Reunión Científica de la Fundación Española de Historia Moderna: (Madrid, 2-4 de junio de 2004), Vol. 1, 2005 (La reina Isabel y las reinas de España: realidad, modelos e imagen historiográfica), Madrid, Fundación Española de Historia Moderna, 2005, págs. 497-522.

9. Véase FRANCO RUBIO, G.A., "El ejercicio del poder en la España del siglo XVIII", en: Melanges de la Casa Velázquez, Vol. 1., no 35, 2001, págs. 51-78. La tertulia y la casa de la cuñada del ministro Carvajal están descritas y elogiadas por la magnificencia y la espléndida biblioteca y el buen gusto (es decir, el Neoclásico), junto a la de otras mujeres de la época, en: FERNÁNDEZ-QUINTANILLA, P., La mujer ilustrada en la España del siglo XVIII, Madrid, Ministerio de Cultura, 1981.

10. Véase FEIJOO, B.J., Defensa de la mujer: Discurso XVI del Teatro Crítico, (edición a cargo de Victoria Sau, Barcelona, Icaria, 1997.

11. Véase MARTíNEZ GAITE, C., Los usos amorosos del dieciocho en España, Madrid, Ediciones Siglo XXI, 1972. En el estudio de la personalidad y características de la mujer del siglo XVIII destacan las obras de Mónica Bolufer Peruga, entre ellas: BOLUFER PERUGA, M. y MORANT DEUSA, I., "Historia de las mujeres e historia de la vida privada. Confluencias historiográficas", en: Studia histórica. Historia Moderna, no 19, 1998, págs. 17-23. y BOLUFER PERUGA, M., Mujeres e Ilustración. La construcción de la feminidad ilustrada, Madrid, Institución Alfonso el Magnánimo, 1998. 
de algunas damas que organizaron reuniones en su casa a las que asistían políticos y embajadores que compartían no sólo amistad sino también unos intereses políticos determinados. Es el caso de la duquesa de Béjar, que reunió en su casa, durante el reinado de Fernando VI, a todos los hombres de la Corte afines a Portugal'12.

Por tanto, las mujeres que ejercieron cargos palatinos fueron intermediarias entre la reina y los hombres de gobierno, a los que estaban unidas por lazos familiares o de amistad a través de la vida cortesana. Pero en algunos casos sobrepasaron las prerrogativas de su cargo y se adentraron en el terreno de la diplomacia, donde actuaron en la defensa de iniciativas políticas e incluso de alianzas internacionales. Y es a este grupo de cortesanas, que a su puesto en la casa real añadían los servicios en la política exterior y en las redes trazadas por los más altos cargos de la Monarquía, al que pertenece Margarita Isabel O’Brien, condesa de Lismore, pieza clave en el entramado ensenadista, espía en la corte francesa, y que es el personaje central de este artículo.

A primera vista la dama, como dueña de honor de Isabel de Farnesio, engrosó la importante nómina de irlandesas que formaron parte de su séquito. La mayoría de ellas pertenecían a familias jacobitas -y no sólo de primera generaciónque sirvieron a los Borbones españoles -y antes a los franceses- a condición de ver restablecido en el trono de Saint James a un Estuardo católico.

La alianza de la Monarquía borbónica con la dinastía Estuardo se remonta a la Guerra de Sucesión Española y a la consecución del tratado de Utrecht. La defensa de un rey católico, expulsado de Inglaterra por su confesión religiosa, fue la excusa perfecta de una alianza entre dos dinastías que desde entonces compartieron intereses, concretamente por el capítulo del tratado referido a las actas de renunciación, que excluían a Felipe $V$ del trono de Francia y por la pérdida de Gibraltar y de Menorca a manos de Inglaterra. Por ello, España participó en las cinco expediciones de los Estuardo para recuperar el trono inglés desde 1715 a $1745^{13}$. Hay que destacar que desde 1734 se reforzó la unión existente entre España y la causa jacobita, a raíz de la participación de Carlos Eduardo, primogénito de la familia, en la conquista del trono de Nápoles para el infante don Car$\operatorname{los}^{14}$. "El joven pretendiente" Estuardo, de tan sólo quince años, bajo la protección

12. Las referencias a las visitas de Keene a la casa de la duquesa de Béjar para reunirse con los diplomáticos y cortesanos de procedencia portuguesa se suceden a lo largo de su correspondencia. Véase The private correspondence of Sir Benjamin Keene, (Edición e introducción by Richard Lodge), Cambridge, Cambridge University Press, 1933.

13. La vinculación de España con la Casa Estuardo ha sido estudiada en profundidad en: CARPIO, M.J., España y los últimos Estuardos, Madrid, 1952.

14. La muerte de Antonio Farnesio y la política revisionista de Felipe $V$ dieron al infante Carlos la oportunidad de conseguir un trono, recuperando los territorios de Nápoles y Sicilia, perdidos en el tratado de Utrech. Un episodio que ha sido retratado con detalle en la magnífica obra: BÉTHENCOURT MASSIEU, A., Patiño en la política internacional de Felipe $V$, n⿳0 1 , Estudios y documentos de Historia Moderna, 1954, pág. 17. 
de su tío el duque de Berwick ${ }^{15}$, se estrenó en las armas luchando con los refuerzos enviados por el papado al ejército español en el fuerte de Gaeta.

Allí logró el reconocimiento miliar y la protección del nuevo rey de las dos Sicilias, de quien se dice logró la promesa de que le devolvería sus servicios cuando llegara la ocasión ${ }^{16}$. Así mismo, la alianza y la lucha por los intereses de las dos dinastías establecieron lazos clientelares entre los hombres que les sirvieron en el terreno militar y político. Es usual que los miembros de las familias jacobitas que sirvieron lo hicieran en el ejército o, algunos, como personal cortesano, y que conozcamos más a los hombres que a las mujeres, puesto que en general, éstas hicieron labores calladas como correspondía a su situación en la época.

Este artículo está dedicado a plasmar la trayectoria de una de estas mujeres, Margarita Isabel O'Brien, condesa de Lismore, una dama que ya despertó el interés de importantes historiadores como Dolores Gómez Molleda ${ }^{17}$ o Didier Ozanam $^{18}$, que repararon en ella al estudiar la correspondencia de Huéscar con el Ensenada y con Carvajal, respectivamente. Las misivas de los principales ministros de Fernando VI y la condesa muestran el papel que jugó ésta como agente de la Monarquía española y su relación privilegiada con algunos de los principales hombres del gobierno de Luis XV. Su correspondencia particular con el duque de Huéscar, conservada en el Archivo de la Casa de Alba ${ }^{19}$, constituye la

15. Jacobo Francisco Fizt-James Stuart, barón de Tynemouth, segundo duque de Berwick, hijo del primer duque de Berwick y de Honoria de Burgh. Acompañó a Jacobo III, en 1715. Fue expulsado del ejército francés a petición del rey de Inglaterra Jorge I y huyó a Holanda. Su padre, el duque de Berwick le dio el título de Grande de España de clase primera y los ducados de Liria y Jérica. Fue un hombre brillante y encantador que fascinó al príncipe Carlos Eduardo Estuardo, su primo. Tanto él como su familia siguieron al servicio de la Monarquía española donde consiguieron enriquecerse y ganar prestigio. Liria más tarde actúo como apoderado en el matrimonio del príncipe Carlos con Luisa Stolberg, en 1772. Esta semblanza del duque de Berwick se encuentra en: McKERRACHER, M., The Jacobite Dictionary, Glasgow, Neil Wilson Publishing Ltd, 2007, pág. 88. Sobre la figura del duque de Berwick véase también: FITZ-JAMES STUART y PORTOCARRERO, C.M. (duque de Alba), Conquista de Nápoles y Sicilia y relación de Moscovia, (precede una noticia de la vida y escritos del autor por A. Paz y Meliá), Madrid, 1890.

16. CARPIO, M.J., España y los últimos Estuardos..., págs. 278-283.

17. GÓMEZ MOLLEDA, M.D., El marqués de la Ensenada a través de su correspondencia íntima, Madrid, Eidos, 2, 1955.

18. OZANAM, D., La diplomacia de Fernando VI. Correspondencia entre Carvajal y Huéscar 1746-1749, C.S.I.C. Escuela de Historia Moderna, Madrid, 1955.

19. La correspondencia de Madame O'Brien y el duque de Huéscar se conserva en el archivo de la Casa de Alba y está catalogada con la referencia ADA., C. 204, no 5 . Se trata de un legajo que aparece en el índice con el título: "Correspondencia de Mademoiselle O'Brien con el duque de Huéscar 1746-1749". En él se conservan las cartas que Margarita Isabel O'Brien intercambió con el duque de Huéscar, Fernando Álvarez de Toledo. Las cartas están escritas en francés y algunas tienen parte de su contenido cifrado, del que se conserva la clave de cifra en el propio legajo. Agradezco a la Fundación Casa de Alba el trato exquisito y las facilidades que me ha dado para consultar sus fondos. 
fuente más copiosa y la base principal de este trabajo. Así, a través de sus cartas, veremos en Margarita O'Brien un ejemplo muy representativo de la capacidad de acción de la mujer como instrumento de la política exterior, valiéndose en este caso de su carácter intrigante y extraordinaria habilidad para hacer útiles sus relaciones sociales, no sólo en el ejercicio del cargo real sino también a través de todos y cada uno de los resortes de la vida cortesana, aprovechando, en todo momento, la posición ventajosa que le daba el ser la esposa del embajador de la casa Estuardo en Francia.

El papel de la condesa de Lismore es especialmente reseñable, pues traspasaba su competencia oficial, como dueña de honor, participando en la red de espías de Ensenada como su agente dentro del séquito de damas que servían a la infanta María Teresa, esposa del delfín de Francia. Margarita constituye un ejemplo singular dentro de la red de informadores del marqués ${ }^{20}$, pues demuestra cómo en ella estuvieron implicados personajes de la Corte, entre ellos mujeres, unidas a Ensenada por relaciones de estrecha amistad, como sucedió con la marquesa de Salas, o bien como en este caso, por la simple utilidad política. En su misión de agente Margarita Isabel O'Brien cultivó su amistad con algunos de los principales personajes del gobierno de Luis XV, como el cardenal de Tencin y los hermanos Argenson. La información que obtenía, a través de los distintos cauces de la vida cortesana francesa, la transmitía mediante su correspondencia confidencial, de la que se conserva una parte significativa. El carácter cifrado de una buena parte de ella y la existencia de una cifra propia ${ }^{21}$ no deja lugar a dudas sobre su buen conocimiento de la diplomacia y sobre su dominio de las técnicas de espionaje ${ }^{22}$.

\section{Una perfecta cortesana}

Margarita O'Brien aparece ligada a la sagrada causa jacobita a raíz de su matrimonio con el conde de Lismore, celebrado en 1726 y protegida desde la cuna por importantes miembros de las cortes de los Borbones, tanto en Francia como en España. Según hizo constar en su expediente descendía del famoso héroe irlandés Brian Borowh ${ }^{23}$ y pertenecía a la familia de los Clare, refugiados irlande-

20. TARACHA, C., "El marqués de la Ensenada y los servicios secretos en la época española de Fernando VI"..., pág. 112. Véase también GONZÁLEZ CAIZÁN, C., La red política del marqués de la Ensenada, Madrid, Fundación Jorge Juan, 2004.

21. LORENZO CADARSO, P.L., "Los documentos cifrados en la Corte de Fernando VI (1746-1759)", en: Espacio, tiempo y forma. Serie VI, Historia moderna, no 11, 1998, págs. 359380, págs. 348-353.

22. TARACHA, C., "Informes de los servicios de inteligencia españoles del siglo XVIII: contenido, estructura, formas de envío de la información secreta", en: Conferencia Internacional. En la paz como en la guerra. El espionaje como instrumento de la política de Estado, Lublín, 2010.

23. AGP, Personal, Caja 749, expediente 9. 
ses que ocupaban puestos menores en la corte española ${ }^{24}$. Sin embargo, el único dato fidedigno que pudo aportar sobre su ascendencia fue que su madre era la hija pequeña de Mr. Ballecour, gobernador, durante el dominio español, de Dovay en Flandes. La imprecisión de la información sobre su ascendencia paterna alimentó en Francia el rumor de que era hija ilegítima del ministro de Estado, el cardenal de Tencin, a quien siempre le unió una estrecha amistad y que se dirigía a ella como "mi bella sobrina"25. Desde esa posición privilegiada pudo contraer un matrimonio ventajoso con Daniel $\mathrm{O}^{\prime}$ Brien $^{26}$, conde de Lismore, pariente lejano suyo y uno de los hombres de máxima confianza del exiliado rey, Jacobo III Estuardo, para quien actuaba de embajador en París ${ }^{27}$.

En su expediente también figura que gracias a las negociaciones realizadas por el cardenal Valenti Gonzaga, Secretario de Estado de España ante la Santa Sede, y por el marqués de Scotti, hombre de confianza de la reina Isabel, el 23 de febrero de $1743^{28}$. Gracias a ellas, con la recomendación del Sumo Pontífice, entró al servicio de la Monarquía española como dueña de honor de Isabel de Farnesio ${ }^{29}$. A primera vista su nombramiento engrosaba la nómina de irlandesas que servían en la Casa de la reina, donde la presencia de extranjeros era una de sus peculiaridades, pues la Farnesio, la conocida "casamentera de Europa", buscaba así ganar lealtades y recompensar servicios en todas las cortes católicas ${ }^{30}$. Sin embargo, Margarita iba a exceder las competencias de su cargo para adentrarse en el terreno de la política exterior española, como agente de Ensenada en la corte de Luis XV.

24. McKERRACHER, M., The Jacobite Dictionary... pág. 176. Véase también ANDÚJAR, F., "Familias irlandesas en el ejército y en la corte Borbónica", en: Extranjeros en el ejército: Militares irlandeses en la sociedad española, 1580-1818, Madrid, 2007, págs. 271-295.

25. Guérin de Tencin (Pierre). 1679-1758. Encargado de negocios en Roma (1721-1724), arzobispo de Embrun (1724-1740), cardenal (1739), arzobispo de Lyon (1740-1758), fue Ilamado a la corte en 1742 como ministro de Estado. En 1751 se retiró del Consejo para dedicarse a su diócesis. Estaba muy unido al conde de Argenson y al mariscal Belleisle. OZANAM, D, La diplomacia de Fernando VI. Correspondencia entre Carvajal y Huescar 1746-1749... pág. 187.

26. Daniel O'Brien, conde de Lismore (1683-1759), Hijo del general Morough O'Brien, u O'Bryan, of Carrisgogunnel de Irlanda, que sirvió en la armada francesa de 1706 a 1720. Daniel O'Brien entró en la armada francesa como cadete a la temprana edad de once años y en 1719 obtuvo el grado de coronel. En 1726 fue nombrado barón de Castle Lyons. Alrededor de 1735 contrajo matrimonio con Margarita Isabel O'Brien. En 1745, Jacobo III le nombró embajador en la corte de Francia. El 7 de febrero de 1747, le fueron dados poderes para negociar con la corte de Madrid. Fue el representante en ambas cortes hasta mayo de 1747, cuando se le nombró Secretario de Estado Jacobita, hasta su muerte en 1759. McKERRACHER, M., The Jacobite Dictionary..., 2007, pág. 176.

27. Ibíd. 176.

28. AGP, Personal, Caja 749 expediente 9.

29. "Por interposición del Papa se sirvió conceder los honores de Señora de Honor con sueldo a Madame O'brien Mujer de Mr. O'brien, ministro que es en París del Rey Jacobo que está en Roma". AGP, Personal, Caja 749 expediente 9.

30. LÓPEZ-CORDÓN CORTEZO, M.V., "la evolución de las damas en los siglos XVII y XVIII"... pág. 1386. 
Hay que hacer constar que su nombramiento estaba directamente relacionado con el afianzamiento de los lazos clientelares entre España y la causa jacobita a raíz de la participación de Carlos Eduardo, primogénito de la familia, en la conquista del trono de Nápoles para el infante don Carlos $^{31}$. La conquista del trono de las dos Sicilias fue uno de los grandes éxitos de la política del secretario favorito de Isabel de Farnesio, José Patiño, y en ella no sólo se unieron más dos dinastías con el objetivo de lograr un trono, sino que también se gestó toda una red de lazos clientelares en torno a la lucha por los intereses de los hijos de la soberana española, a cuyo servicio se sabía que se podía ganar honor y destino. Entre los nuevos servidores de la Monarquía se encontraba don Zenón de Somodevilla, a quien por sus méritos en la organización de la campaña que llevó al infante Carlos al trono de las Dos Sicilias, le fue concedido el título napolitano de marqués de la Ensenada ${ }^{32}$. Y es a través de él, conocido por su buena relación con las damas, como, por estas fechas, Margarita O'Brien comenzó su vinculación con la corte española, al igual que lo hacía Ensenada al volver a España y tener acceso a la corte, al servicio del otro infante que faltaba por colocar en un trono, Felipe. Así lo demuestra Margarita en una de sus cartas, que dirigió en 1739 al conde de Bena y Masserano ${ }^{33}$, ministro español en Moscovia, en la que hace referencia al contacto epistolar que mantenía con el marqués y a las comisiones que realizaba para la Monarquía española ${ }^{34}$. Ensenada vio en ella "un mueble útil ${ }^{35 "}$ para incluir en su red de agentes ya que, de acuerdo a su condición de mujer de clase privilegiada, tenía la educación necesaria para participar en la "conversación política". A ello había que unir la experiencia diplomática adquirida como esposa del embajador francés de la Casa Estuardo, que le daba una relación privilegiada con el "Conseil du Roi" de Luis XV³6.

Todos estos factores no sólo influyeron en su nombramiento sino también en la decisión de que permaneciera en Francia, con el pretexto de ahorrar en el ce-

31. Véase, BÉTHENCOURT MASSIEU, A., Patiño en la política internacional de Felipe V...

32. RODRÍGUEZ VILLA, A., Don Cenón de Somodevilla, marqués de la Ensenada, Madrid, 1878, pág. 6 y apéndice 2 y GÓMEZ URDÁÑEZ, J.L., El proyecto reformista de Ensenada..., pág. 66.

33. Guido-Jacinto Ferrero Fieschi, Conde de Bena, (1690-1750). Capitán de navío (1729), jefe de escuadra (1737), teniente general de la Real Armada (1741), fue después ministro de España en Rusia y en Sajonia. De vuelta a España fue nombrado director general de la Real Armada puesto creado para él. OZANAM, D., La diplomacia de Fernando VI. Correspondencia entre Carvajal y Huescar 1746-1749..., pág. 122.

34. ADA, C. 204, no 5, Carta escrita por el ministro de Moscovia a Mme. O'Brien fechada el 31 de Junio de 1739 .

35. ADA, C. 204, no 5, Huéscar a Ensenada,16 de mayo de 1746. Agradezco al profesor Didier Ozanam la oportunidad que me dio, por medio del profesor Gómez Urdáñez, mi director de tesis, de transcribir las cartas de Huéscar a Ensenada y viceversa, que él había copiado hacía años en el ADA, junto con mi compañera, la también becaria Ainhoa Reyes Manzano.

36. OZANAM, D., "La diplomacia de los primeros borbones", en: Cuadernos de Investigación Histórica, no 6, 1982, págs. 164-196 
remonial, de acuerdo a las medidas impuestas en la reforma de Alberoni ${ }^{37}$. Con todo ello se le mantuvo el sueldo, de forma que pudiera hacer frente a los ingentes gastos de la corte gala ${ }^{38}$, tal y como figura en su expediente: "... dicha dama ha solicitado después esta señora que se la nombrase para venir a servir, pero la Reina no lo ha acordado por ser la intención de S.M. no aumentar, en esta parte, el número de las Señoras de honor y sólo ha condescendido S.M en que se le de nombramiento y se le de sueldo" 39 .

Hay que destacar que la inclusión de Margarita $\mathrm{O}^{\prime}$ Brien en la corte y en la diplomacia española fue motivo de continuas críticas y recelos, incluso por parte de sus propios valedores, como muestran los comentarios hacia su relación con el arzobispo de Cambrai. Huéscar bromeaba con Carvajal: "Querido Pepe. He empezado a dar tus recados por M. y Mme. O'Brien. En casa está el retrato de Montijo in capite de libri, y después el del arzobispo de Cambray, hijo del Regente y no de su mujer" 40 . También se criticó su ambición por el dinero, por lo que Ensenada avisaba de ello al duque de Huéscar: "La madame O'Brien es tan diablo como expliqué a Vm (...) Esto supuesto no la huya, sírvase con ella con cautela pues considérela capaz de comer a cien carrillos"41. La misma desconfianza tenía Jacobo III $^{42}$ hacia la esposa de su fiel confidente y ministro. Sin embargo, sus hijos vieron en ella un medio para entrar en contacto, tanto con sus aliados españoles como con su principal apoyo en Francia, el cardenal de Ten$\operatorname{cin}^{43}$. No obstante, ella se mostró siempre consciente del papel que había de jugar y no dudó en reconocer su amor por la intriga política, como muestran sus

37. Las repercusiones sobre la reforma de Alberoni en el gasto de la Casa de la reina se encuentran descritas de forma precisa y sintética, en: JURADO SÁNCHEZ, J.J., "Proyectos para reducir el gasto de la Hacienda española durante el siglo XVIII. Diagnóstico, medida y resultados en los intentos de hacer menos costosa la corte", en: Cuadernos de estudios empresariales, 2004, no 14, págs. 105-129.

38. La nómina completa de Margarita Isabel O'Brien se conserva dentro de su expediente personal. El documento demuestra que la casa de la reina mantuvo su sueldo de dueña de honor hasta la fecha de su muerte en 1787 y que a él le fueron añadidas unas pensiones adicionales que ascendieron a la suma de 30.000 reales. Véase AGP, Personal, Caja 749 expediente 9 .

39. AGP, Personal, Caja 749 expediente 9.

40. Huéscar a Carvajal, París 22 de marzo de 1746, op.cit. OZANAM, D, La diplomacia de Fernando VI. Correspondencia entre Carvajal y Huescar 1746-1749... pág. 86.

41. ADA, C. 212, no 12, Ensenada a Huéscar (sin fecha) febrero de 1746.

42. MCKERRACHER, M., The Jacobite Dictionary..., pág. 176.

43. El cardenal de Tencin se sintió siempre deudor de Jacobo III, por mediar a su favor para que obtuviera el capelo cardenalicio. En agradecimiento, el ministro francés apoyó de forma personal e insistente todos los intentos de levantamiento de los Estuardos para la recuperación del trono inglés. De hecho fue al único al que el "joven pretendiente" confió los detalles de su proyecto de expedición de 1745. Véase, McKERRACHER, M., The Jacobite Dictionary... pág 106 y AMADEO PICHOT, M., Historia de Carlos Eduardo, último Príncipe de la Casa de Estuardo, precedida de una historia de la rivalidad de la Inglaterra y de la Escocia, Madrid, 1831, pág. 117. 
palabras: "Mi marido me manda que le diga que usted le ha dicho que yo era un verdadero demonio; yo acepto el título que me da"44. Estas valoraciones, al margen de su veracidad u objetividad, ponen de manifiesto las contradicciones entre el arquetipo y la realidad social de la mujer cortesana en la primera mitad siglo XVIII.

\section{El interés de España en la política francesa}

Las continuas quejas de los reyes españoles a Luis XV por la traición del ministro de exteriores galo, el marqués de Argenson, al negociar una paz con la corte de Turín, en diciembre de $1745^{45}$, Ilevaron a Ensenada, secretario de Guerra, Marina, Hacienda e Indias y secretario del infante desde 174346, a enviar una embajada extraordinaria que trasmitiera la rotunda negativa de la Monarquía española a dicho proyecto ${ }^{47}$. Renato Luis de Argenson había prometido la adhesión de España a un armisticio, que implicaba su renuncia sobre los ducados de Parma y Toscana, provocando las iras encendidas de la soberana española que veía peligrar la alianza militar franco-española, en el capítulo referido a sus intereses en el frente italiano, donde buscaba conseguir un ducado para el segundo de sus vástagos, el infante Felipe ${ }^{48}$.

El elegido para encabezar la embajada fue don Fernando de Silva Álvarez de Toledo, duque de Huéscar, de acuerdo a la costumbre de la época de encargar las misiones diplomáticas excepcionales a hombres de la máxima confianza de los monarcas y de sus hombres de gobierno, sin tener en cuenta su experiencia y preparación diplomática ${ }^{49}$. El duque servía a la Monarquía desde 1731, formando

44. ADA, C. 204, no 5, Mme. O'Brien al duque de Huéscar, 22 de octubre de 1746.

45. FERNÁNDEZ ALBADALEJO, P., Los Borbones: dinastía y memoria de nación en la España del siglo XVIII, Madrid, Marcial Pons, pág. 29.

46. La buena relación del marqués de la Ensenada con las damas ha sido señalada por los distintos historiadores que han apuntado como su elección para sustituir a Campillo se atribuye en gran parte a la intercesión de la marquesa de Torrecuso, que servía a Isabel de Farnesio. Véase BOUVIER R. et SOLDEVILLA, C., Ensenada et son temps, París, Editions Fernand Sorlot, 1941, capítulos I y II. El ascenso del marqués de la Ensenada en la corte y el gobierno ha sido descrito de forma precisa en: GÓMEZ URDÁÑEZ, J.L., El proyecto reformista de Ensenada..., capítulo "Zenón de Somodevilla. La sorprendente carrera del déspota", págs. 59-81.

47. ZABALA Y LERA, P., El marqués de Argensón y el Pacto de Familia de 1743, Madrid, Editorial Voluntad, S.A., 1928, pág. 153. El autor dedica un capítulo a la embajada extraordinaria del duque de Huéscar, titulado, "Embajada extraordinaria del duque de Huéscar", págs. 151-223.

48. FERNÁNDEZ ALBADALEJO, P., Los Borbones: dinastía y memoria de nación en la España del siglo XVIII..., pág. 28. Las motivaciones y desarrollo de la empresa del infante Felipe, en el contexto de la Guerra de Sucesión Austriaca, han sido descritas en: DEL CANTILLO, A., Tratados, convenios y declaraciones de paz y de comercio que han hecho los monarcas españoles desde el año 1700 hasta el día de hoy, Madrid, 1843, nota 18.

49. OZANAM, D., "La diplomacia de los primeros borbones", en: Cuadernos de Investigación Histórica, no 6, 1982, págs. 164-196. 
parte del regimiento de infantería de Mallorca y ocupaba el cargo de gentilhombre de cámara ${ }^{50}$. Luchó en las campañas de Italia de 1742 y 1743, bajo las órdenes del marques de la Mina, amigo de Ensenada, como él mismo por entonces. Al marqués de la Ensenada se atribuyó su ascenso en la corte al ser nombrado Guardia de Corps ${ }^{51}$, así como su designación para esta embajada extraordinaria con la que comenzaba su carrera diplomática. Hay que precisar que con esta elección Ensenada, conocido como "el ministro que quería rodearse de todo y que todo lo quería saber", iba a disponer de una información de primera mano sobre la situación de la corte y el gobierno francés respecto a la política exterior española, ya que el embajador oficial, Campoflorido, mantenía más vínculos con el secretario de Estado, el marqués de ViIlarías, que con él. Con este fin, entregó a Huéscar, antes de su partida, unas "instrucciones secretas" en las que dibujó el complejo retablo que era la corte francesa y en el que figuraban los agentes con los que allí había de contar, entre los que se hallaba Margarita Isabel O'Brien ${ }^{52}$.

La condesa de Lismore, de acuerdo a su condición de dueña de honor de la reina española, formaba parte del séquito de damas de la infanta María Teresa que, desde su matrimonio con el futuro Luis XVI, cumplía con su papel de delfina y, por petición expresa de Isabel de Farnesio, utilizaba esta posición privilegiada para interceder por su hermano, el infante Felipe. Una carta de Margarita $\mathrm{O}^{\prime}$ Brien $^{53}$ da constancia de la implicación directa de la infanta en las maniobras del marqués de la Ensenada en la causa del infante y de sus éxitos al hacer valer sus opiniones ante los reyes franceses ${ }^{54}$.

La actividad diplomática del duque de Huéscar estuvo marcada por la creciente tensión existente entre él y el marqués de Argensón durante las audiencias con Luis XV. El ministro francés insistía vehementemente en la irracionalidad y sentimentalismo del rechazo de los reyes españoles a la paz con Turín y denunciaba sus intenciones de utilizar la alianza con Francia, únicamente a favor de los intereses del segundo de sus vástagos. El ímpetu de sus alegatos hacia honor

50. AGP, Personal, Caja 389, expediente 6. Los cargos que ocupó el duque de Huéscar están también recogidos en: FITZ-JAMES STUART y FALCÓ, J., El duque de Huéscar, en: Boletín de la Real Academia de la Historia, tomo CXIX (julio-diciembre de 1746), págs. 7-20 y en OZANAM, D., La diplomacia de Fernando VI. Correspondencia entre Carvajal y Huescar 1746-1749... págs. 9 y 10.

51. "El conde de Montijo lo había solicitado para su hermano el conde de Mancera. Fue la reina quien, con ayuda de Ensenada, inclinó la balanza a favor de Huéscar" (Vauréal a Amelot, 15 de febrero de 1744, A.E.C.P., Espagne 478, fols. 93-94), op.cit. OZANAM, D., La diplomacia de Fernando VI. Correspondencia entre Carvajal y Huescar 1746-1749..., pág. 10.

52. RODRíGUEZ VILLA, A., Don Cenón de Somodevilla, marqués de la Ensenada..., págs. 66-76.

53. ADA, C. 204, no 5, Mme. O’Brien al duque de Huéscar, 30 de abril de 1746. Carta adjunta de la Señora Delfina dirigida al marqués de la Ensenada.

54. Correspondencia entre Isabel de Farnesio y la infanta María Teresa, AHN, Estado, legajo, 4026. 
al apelativo "la bete ${ }^{55 "}$ por el que era conocido en la corte francesa. Huéscar contravenía sus argumentos, en un tono más moderado pero igualmente firme y acusaba de traidor al ministro francés por sus negociaciones con Turín a espaldas del propio monarca galo y en contra de la alianza española sellada en el Segundo Pacto de Familia. Argenson trataba también de descalificar al embajador español, refiriéndose a él con el calificativo peyorativo "mis à la mode de le prôner"56 y se hacía eco de las valoraciones negativas que le había dedicado el obispo de Rennes que lo había descrito como "un hombre poco sincero, altivo o rastrero según la ocasión, más fastuoso que magnifico y ardiente partidario de la Casa de Austria" 57 .

Pero Luis XV continuaba sin tomar una decisión contundente por lo que el duque de Huéscar decidió participar intensamente en la vida cortesana y entrar en las cábalas -los partidos- para conocer así la posición de los hombres y mujeres que pudieran inclinar el espíritu del monarca hacia las pretensiones españolas. Se hizo asiduo a teatros, tertulias y salones, entre los que destacaba la casa de madame Pompadour, favorita de Luis XV y que tenía un ascendiente cada vez mayor, como le apuntó Margarita O’Brien: "en Francia la Pompadour parece estar más que nunca"58. Su casa era frecuentada por los principales ministros y embajadores, pero las visitas del duque resultaron infructuosas a la hora de ganarse a la dama ${ }^{59}$. No obstante, Huéscar logró sondear la opinión de los ministros franceses y comprobar la oposición férrea del ministro de Marina, el conde de Maurepas, y del conde de Noailles, que se obstinaban en defender los derechos del infante y la necesidad de que las dos Coronas salvaguardaran su unión ${ }^{60}$.

En esta actividad cortesana de Fernando de Silva Álvarez de Toledo destacó el papel jugado por Margarita O'Brien que actúo de intermediaria con el marqués de Argenson y sus partidarios. No hay que olvidar que la dama organizaba reuniones en su casa a las que asistían asiduamente el cardenal de Tencin, el propio marqués de $\operatorname{Argenson}^{61}$ y su hermano el conde de Argen-

55. "La bete: apelativo con el que era conocido el marqués de Argenson en Versalles por su "aire de bonhomie y su tono rústico" ZABALA Y LERA, P., El marqués de Argensón y el Pacto de Familia de $1743 \ldots$... pág. 70.

56. BAUDRILLART, A., Philippe $V$ et la cour de France: d'après des documents inédits tirés des archives espagnoles de Simancas et d'Alcala de Hénarès, et des Archives du Ministère des Affaires Etrangères à Paris, tomo V, París, 1901, pág. 364.

57. ZABALA Y LERA, P., El marqués de Argensón y el Pacto de Familia de 1743..., pág. 155.

58. ADA, C. 204, no 5, Mme. O’Brien al duque de Huéscar, 30 de abril de 1746. Carta adjunta de la Señora Delfina.

59. BAUDRILLART, A., Philippe $V$ et la cour de France..., pág. 367.

60. BAUDRILLART, A., Philippe $V$ et la cour de France..., pág. 367.

61. René Luis de Voyer, marqués de Argenson 1694-1757. Consejero de Estado en 1720, canciller del duque de Orleans en 1741, ministro de Estado y secretario de Estado de asuntos exteriores del 18 de noviembre de 1744 al 10 de enero de 1747. OZANAM, D., La diplomacia de Fernando VI. Correspondencia entre Carvajal y Huescar 1746-1749..., pág. 114. 
son ${ }^{62}$. El contacto entre Margarita y el duque de Huéscar se intensificó, al participar éste en alguna de sus reuniones y al visitarla con asiduidad para intercambiar información y correspondencia confidencial que luego remitían al marqués de la Ensenada ${ }^{63}$. Un clima de confianza que la condesa de Lismore no dudó en aprovechar para actuar de enlace entre Ensenada y los príncipes de la Casa Estuardo, como demuestra la existencia, en la correspondencia de la dama, de cartas del duque de York, hermano de Carlos Eduardo dirigidas a Huéscar y a Ensenada ${ }^{64}$.

\section{La causa jacobita}

Además del servicio de Margarita O’Brien a la política franco-española en la causa del Infante, Margarita servía también a la causa Estuardo. El 16 de abril de 1746, la causa jacobita sufrió la más dura de sus derrotas en la batalla de Culloden, marcando el principio del fin de la aventura del "joven pretendiente" por recuperar el trono inglés. Sin embargo, Carlos Estuardo mantenía aún sus esperanzas al haber logrado, después, la victoria sobre el ejército de lord London en el fuerte de Inverness y por los triunfos en Escocia de algunos de sus generales ${ }^{65}$. Su ambición incansable le llevó a diseñar un ambicioso proyecto de contraataque para el que necesitaba el apoyo militar de Francia, de España y de todos aqueIlos jacobitas que quedaban en el gobierno de Londres. Encargó a su ayuda de campo, Arthur Lally, comunicar el plan a sus posibles aliados y éste, a su vez, confió en Margarita O’Brien para que lo trasmitiera a Huéscar y Ensenada, como muestra esta carta:

En el momento en el que él Ilega de Escocia uno de los ayudantes de campo de S.A.R., el Señor Príncipe de Gales, trae la noticia de que este

62. Marc-Pierre de Voyer Paulmy, conde de Argenson (1696-1764) "Maître des requêtes (1719), teniente general de policía (1720-1724), intendente de Tours (1721), consejero de Estado (1724), intendente de París (1740), ministro de Estado (1742) y secretario de Estado y de Guerra de 1743 a 1757. Op. cit. OZANAM, D., La diplomacia de Fernando VI. Correspondencia entre Carvajal y Huescar 1746-1749..., pág. 221.

63. "Como yo ignoro cuando será la hora que V.E. encuentre un momento para hacer el honor de pasar por mi casa, yo le suplico quiera bien reenviar la carta al Señor marqués de la Ensenada, que apenas ayer me entregó los términos para leerla, para no perder un momento en el envío", en: ADA, Caja 204, Mme. O’Brien al duque de Huéscar, 13 de mayo de 1746.

64. ADA, C. 204, no 5, Mme. O’Brien al duque de Huéscar, 25 de octubre de 1746 (referencia al documento adjunto). Una alusión más clara al papel de la condesa de Lismore como agente de la causa Estuardo, en: ADA, C. 204, no 5, Mme. O'Brien al duque de Huéscar 13 de mayo (no figura el año): "Yo suplico a V.E. quiera tener a bien la bondad de enviarme con los otros tres paquetes, la carta del marqués de la Ensenada, que contiene una para el duque de York para este ministro, como también un (fragmento perdido) V.E. puede leerla e incluir lo que considere oportuno...".

65. AMADEO PICHOT, M., Historia de Carlos Eduardo, último Príncipe de la Casa de Estuardo..., Vol. III, pág. 234. 
príncipe ha sacado varios pequeños provechos; y de la pérdida total del cuerpo comandado por lord London; que era de 35.000 hombres de los cuales no queda ninguno; este general se ha salvado solo, en la isla de Skia"66.

Y una parte de este cuerpo tomó parte en la armada del príncipe; el cual a la partida de sus ayudantes de campo, el 18 de este mes se preparaba a marchar al ducado de Cumberland, cuyo terror era extremo; pero a ese valeroso príncipe le faltaba dinero, si él lo tuviera en quince días sería Señor de toda Escocia; porque su armada reuniría justo los 14.000 hombres y él podría tener 20 si los fondos no le faltaran, que y yo temo mucho que el Señor Brown que trae 252.000 H., sea cogido por los ingleses; dios quiera que el dinero del lado de la Bretaña pueda Ilegar.

Creo Señor debo no tardar a enviar sus noticias a V.E., yo me siento orgullosa de tener honor de verla mañana o pasado mañana tengo un deseo extremo; de contarle a S.E. el marqués de la Ensenada y reenviarle mis cartas a V.E... ${ }^{67}$.

Pero las peticiones de ayuda fueron desoídas porque Francia, consciente del poder del ejército inglés y de su empeño en eliminar la causa jacobita, decidió no intervenir en Escocia y ordenó a los 10.000 hombres que tenía preparados en las costas de Dunkerke, Calais y Bologna, para defender al "joven pretendiente", que protegieran únicamente el frente norte ${ }^{68}$. Privado del auxilio de los ejércitos extranjeros, los clanes escoceses también le retiraron su apoyo. El ejército inglés intensificó sus esfuerzos en dar caza a Carlos Eduardo Estuardo y acabar de esta manera con toda posibilidad de sublevación. Margarita $\mathrm{O}^{\prime}$ Brien hubo de informar de esta complicada situación y transmitir las peticiones de clemencia para los prisioneros jacobitas ${ }^{69}$. Así, Carlos Estuardo, que en agosto del año anterior se había proclamado rey de Inglaterra, se vio obligado a recurrir a toda clase de argucias para esquivar las tropas de su acérrimo enemigo, Jorge II y poder llegar a Francia donde le habían ofrecido refugio junto a los 5.000 hombres que tenía bajo su mando ${ }^{70}$.

Pero, a pesar de la vieja alianza, la causa Estuardo ocupaba un plano muy secundario en las preocupaciones de Francia y más aún en las de España. La corte de Turín había abandonado las negociaciones con Francia para aliarse con Austria, derrotando a las tropas franco-españolas del infante Felipe, que fueron obli-

66. ADA, C. 204, no 5, Mme. O’Brien al duque de Huéscar, 30 de abril de 1746. En cifra.

67. ADA, C. 204, no 5, Mme. O’Brien al duque de Huéscar, 30 de abril de 1746. En cifra.

68. BLACK, J., Culloden and the '45, Nueva York, St. Martin Press, 1990, pág. 60.

69. AMADEO PICHOT, M., Historia de Carlos Eduardo, último Príncipe de la Casa de Estuardo..., Vol. IV, pág. 16 y BLACK, J., Culloden and the '45... pág. 181.

70. ADA, C. 204, no 5, Mme. O’Brien al duque de Huéscar, 27 de junio de 1746. En cifra. 
gadas a abandonar Milán y replegarse en el sitio de Alejandría ${ }^{71}$. Francia se quedó sin más bazas militares que las victorias de su ejército, encabezado por Mauricio de Sajonia, que había logrado entrar en Bruselas y conquistar varias plazas de Holanda. Ante esta situación la paz se presentaba como la única solución viable y obligó a cambiar las líneas de la política exterior francesa que necesitaba, de un lado contar con el respaldo de Inglaterra y de otro recuperar la confianza de España en el Pacto de Familia. Argenson planteó el proyecto conocido como "Plan de Bruselas", firmado el 20 de mayo de 1746, en el que Francia renunciaba a la conquista de Holanda y al establecimiento del infante Felipe en Toscana ${ }^{72}$. Ante estos cambios, el ministro de exteriores se encontraba en una situación límite, cada vez estaba más aislado dentro del gobierno y sólo la lealtad al monarca le mantenía en su cargo.

La correspondencia de Margarita O’Brien da constancia de la pérdida de poder de Argenson en el gobierno francés y de sus intentos de acercar posiciones con España. Sus cartas muestran que el cardenal de Tencin se valía de ella para desmarcarse de la actuación del ministro de exteriores ${ }^{73}$ y tratar de conseguir el favor del duque de Huéscar, lisonjeándolo, insistentemente, con promesas de intercesión para la mariscalía de Francia ${ }^{74}$. Por su parte. Argenson solicitaba a Margarita reunirse con el duque para manifestarle su más firme adhesión a España ${ }^{75}$.

\section{Las dificultades de la Unión de las dos Coronas}

Al poco tiempo llegó el final de la política del marqués de Argenson, que se confirmó con el envío a Madrid del marqués de Noailles, en calidad de embajador extraordinario, con la misión de recuperar la buena armonía entre las dos Coronas. Para el duque de Huéscar esta medida respondía a la intromisión de Campoflorido, en su labor diplomática y le dejaba aislado y fuera de lugar en la corte francesa. Por ello acordó con Ensenada su abandono de París y su incorporación al ejército del infante. El 14 de mayo de 1746 se despidió de Luis XV y partió hacia el frente, finalizando así su primera experiencia diplomática ${ }^{76}$. En ella Don Fernando de Silva Álvarez de Toledo se había granjeado fama de fatuo e indolente por su asiduidad a la vida cortesana, donde trataba de ganarse voluntades sin tener reparo en recurrir a la venalidad cuando lo consideraba necesario ${ }^{77}$. No obs-

71. Sobre la acción de las tropas franco-españolas en el frente italiano y las maniobras en él realizadas, véase MELENDRERAS GIMENO, M.C., Las Campañas de Italia durante los años 1743-1748, Murcia, Editorial Universidad de Murcia, 1987.

72. SOBOUL, A., LEMMARCH, G. y FOGEL, M., El siglo de las luces, vol. I., Los inicios (1715-1750), Madrid, Akal, 1993, pág. 831.

73. BAUDRILLART, A., Philippe V et la cour de France..., pág. 367.

74. ZABALA Y LERA, P., El marqués de Argensón y el Pacto de Familia..., pág. 185.

75. ADA, C. 204, no 5, Mme. O'Brien al duque de Huéscar, 28 de abril de 1746.

76. ZABALA Y LERA, P., El marqués de Argensón y el Pacto de Familia..., pág. 218.

77. GÓMEZ URDÁÑ̃EZ, J.L., El proyecto reformista de Ensenada..., pág. 74. 
tante, es importante destacar que el duque se había conducido, durante toda su embajada, bajo la guía y mirada del marqués de la Ensenada y había sufrido en sus carnes la tensión creciente de éste, con el secretario de Estado, Villarías y el embajador español en Francia, Campoflorido ${ }^{78}$. Huéscar compartía el rechazo del marqués hacia ellos, pues consideraba que sus actuaciones subordinaban España ante Francia, con el fin de salvaguardar, a toda costa, los intereses del infante. Así, su carácter de caballero castellano, le llevó a afirmar con rotundidad: "nuestra personalidad internacional queda suprimida por falta de capacidad para ostentarla y nuestro papel reducido a tener que vivir en total subordinación con los dictámenes de un tutor interesado ${ }^{79}$.

La efímera incorporación ${ }^{80}$ al ejército del duque de Huéscar supuso algunos cambios en su relación con Margarita O'Brien. El contacto epistolar confidencial se mantuvo, convirtiéndose, además, en un importante vehículo de comunicación entre Tencin, los hermanos Argenson y el mariscal de Maillebois, como se muestra en este párrafo: "Madame O'Brien, se ha provisto de comisiones que le ha dado en su carta el duque de Huéscar para el cardenal de Tencin y el marqués de Argenson, es por cuenta de madame O'Brien, el asegurar al duque de Huéscar una sincera conexión, y una amistad tierna ${ }^{81 " . ~ E l ~ c o n t e n i d o ~ d e ~ l a s ~ m i-~}$ sivas refleja la posición de los ministros franceses sobre las derrotas bélicas y los conflictos internos de las tropas galihispanas. A través de estas cartas, el cardenal de Tencin manifestó su firme creencia de que las derrotas se debían a la mala acción del general Castelar y a la necesidad de que fuera sustituído en el mando por el general conde de Gages ${ }^{82}$. Por la misma vía, el marqués de Argenson culpaba de los fracasos en Italia a la desobediencia del ejército español, como se ve en el siguiente párrafo:

El Marqués de Argenson habla seguidamente a Mme. O’Brien de la posición cruel donde se está en Italia o todo lo que nos separa y nos debilita, mientras que los enemigos aumentan y se hacen cada vez más fuertes y más insolentes (...); España nos ha desobedecido en cuanto nosotros le habíamos hecho realizar unas instrucciones, las circunstancias han cambiado la miseria les ha cambiado los corazones y las cabezas podrían ejecutarse por los sacrificios hechos ${ }^{83}$.

78. GÓMEZ MOLLEDA, D., El marqués de la Ensenada a través de su correspondencia íntima, Madrid, Eidos, 2, 1955, pág. 12. GÓMEZ URDÁÑ̃EZ, J.L., El proyecto reformista de Ensenada..., págs. 69-81.

79. ZABALA Y LERA, P., El marqués de Argensón y el Pacto de Familia..., pág. 216.

80. OZANAM, D., La diplomacia de Fernando VI. Correspondencia entre Carvajal y Huescar 1746-1749..., pág. 10.

81. ADA, C. 204, no 5, Mme. O'Brien al duque de Huéscar, 10 de julio de 1746. En cifra.

82. ADA, C. 204, no 5, Mme. O'Brien al duque de Huéscar, 27de junio de 1746. En cifra.

83. ADA, C. 204, no 5, Mme. O’Brien al duque de Huéscar, 27de junio de 1746. En cifra. 
Cabe destacar que los desacuerdos sobre la actuación militar española iban acompañados de una máscara de adulación hacia el duque de Huéscar, al que si antes tachaban de fatuo, intrigante y vago, ahora describían como "caballero castellano, es decir, un hombre de honor y de palabra que ama a su patria y que prefiere su gloria a todas las comodidades de la vida ${ }^{44}$." La estrategia de los ministros franceses consistía en mostrar una cierta aquiescencia con la política española a fin de conseguir su control. Ensenada se jactaba de saber cómo utilizaban a Margarita O'Brien para ello y señalaba que, en el contenido de sus misivas, se veía claramente la intención de no entregar las tropas galihispanas al mando español pues, como bien apuntaba su fiel Montemar, los verdaderos objetivos de Francia no estaban en Italia sino en asegurarse el frente norte ${ }^{85}$. Por tanto, la condesa de Lismore era utilizada como agente, tanto por los ministros franceses como por los españoles y, en consecuencia, sus cartas eran recibidas con mucho interés aunque con suma cautela, como lo reflejan las palabras de Ensenada: "Las cartas de la O’Brien que recibí hoy no he podido leer todavía ni escribo en este extraordinario que a $\mathrm{Vm}$. sólo, pero ella refiere conversaciones que tiene con Argenson y con Tencin y que es diablo Vm. no lo ignora" ${ }^{\prime \prime 6}$.

A pesar de que el frente italiano centraba las relaciones diplomáticas entre Francia y España, Margarita siguió tratando de aprovechar su papel de agente para interceder a favor de los Estuardo. Informó de la incertidumbre acerca del paradero del "joven pretendiente" tras su huída del ejército inglés: "V.E. no ignoráis que no se ha venido a saber de Escocia, más que la vuelta de las fragatas que partieron de Nantes (hace) dos meses, yo tengo un agobio mortal ${ }^{87}$ ". También actúo de intermediaria con los aliados jacobitas cuando el marqués de Argenson le encargó, de forma explícita, que transmitiera a Huéscar y a Ensenada sus intenciones ante la Ilegada a Francia del "joven pretendiente". Con el fin de evitar tensiones con Inglaterra, el ministro de exteriores quería establecer a Carlos Eduardo como vicario general en Francia, con toda su corte de jacobitas derrotados y así evitar que volviera a postularse por el trono inglés:

El marqués de Argensón ha enviado a O'Brien el proyecto por el que había de dar cuenta a Huéscar, pero exigiéndole garantía de O’Brien señalándole a Ensenada que no nombre a Argenson, mientras que O'Brien ha mandado la verdad a Ensenada. Se trata de tiempo, dejar vivir al príncipe Eduardo sin la alta y base naviera, con el título de vicario general y que Francia daría al Príncipe Eduardo gran subsidio. Tendría una especie de corte compuesta de gente de la Provenza e inglesa. Argenson quería que este proyecto fuera simplemente enviado a España por el Papa y el

84. ADA, C. 204, no 5, Mme. O’Brien al duque de Huéscar, 27de junio de 1746. En cifra. 85. GÓMEZ URDÁÑEZ, J.L., El proyecto reformista del marqués de la Ensenada..., pág. 76.

86. ADA, C. 202, no 12, Ensenada a Huéscar, 15 de agosto de 1746.

87. ADA, C. 204, nº 5, Mme. O’Brien al duque de Huéscar, 11 de junio de 1746. 
Rey Cristianísimo y a Ensenada por O’Brien sin hacer mención de Argenson, ya que el proyecto de Argenson es anterior a que el Rey supiera sobre todo esto, los sentimientos de S.M.C. y la Reina y O'Brien es sacrificada sin remordimiento si se supiera que $\mathrm{O}^{\prime}$ Brien ha dicho este secreto y la verdad a Huescar y a Ensenada pero si por desgracia a O'Brien ella tendría al menos el consuelo de ser sacrificada habiendo tenido la ocasión de hacer su deber.

O’Brien cree no tener necesidad de pedir a Huescar el más grande secreto $^{88}$.

Hay que precisar que las palabras de Margarita muestran que en la realización de sus servicios quería dejar claro que su lealtad a la Monarquía española estaba por encima de sus buenas relaciones con Argenson, traspasando así el papel de mera intermediaria y anteponiendo su lealtad y servicio al círculo de Ensenada.

Antes de que el derrotado Carlos Eduardo Estuardo llegara a las costas de Francia se produjo un nuevo giro en las relaciones franco-españolas, por el fallecimiento de Felipe V, el 9 de julio de 1746. La correspondencia de la condesa de Lismore muestra las conjeturas e incertidumbres que había en la corte francesa ante el cambio de reinado: "Su Majestad Cristianísima y todos los ministros han tomado la muerte de S.M.C. con poco dolor y eso por dos razones la una por que de eso ellos creen que devolverá la Paz, y más les alegrará la otra, porque será el ahogo de Campoflorido" ${ }^{\prime 9}$. Los ministros franceses se hacían eco en sus cartas de las valoraciones transmitidas por su embajador, que escribió que el nuevo rey: "amaría tanto la paz, como su padre amó la guerra", a lo que añadió que "si italiano fue el gobierno de España durante el reinado de Felipe $\mathrm{V}$ ahora iba a ser castellano y nacional"90. La incertidumbre también era compartida por Huéscar que dejó en suspenso su incorporación al ejército del infante en espera de conocer el nuevo papel que habría de ejercer en la corte fernandina. Por su parte, Margarita O’Brien veía peligrar su posición, pues ésta dependía, en gran medida, de su cargo de dueña de honor de Isabel de Farnesio, odiada madrastra del nuevo rey. Ante su incierto futuro la dama no dudó en acogerse a la protección de Huéscar y a la de Ensenada, apelando a su lealtad y a los servicios prestados a la Monarquía, como muestra esta misiva:

Señor, vos conocéis mis sentimientos, mi respeto sin límites por la corte de España así que mi aplicación continua por sus intereses, todo eso conoce, y representaré (volveré a servir) al nuevo Rey, podría rendir homenaje digno de su protección, yo he escrito esta mañana a S.E. el Marqués

88. ADA, C. 204, no 5, Mme. O'Brien al duque de Huéscar, 27 de junio de 1746. En cifra.

89. ADA, C. 204, no 5, Mme. O'Brien al duque de Huéscar, 18 de julio de 1746. En cifra.

90. ZABALA Y LARA, P., El marqués de Argensón y el Pacto de Familia..., pág. 245. 
de la Ensenada para suplicarle que no me abandone, yo le hago Señor la misma plegaría, guíeme, condúzcame, que pasos debo hacer, yo no ejecutaré ninguno sin vuestro parecer, y los suyos. Otro temor acaba de agobiarme, yo ignoro cómo Ensenada está con S.M.C., y eso me hace temblar pero mi apego por Ensenada, está por encima de los acontecimientos, y como tal estuviera, y no variará para Ensenada, y yo estaré honrada de ser siempre su amiga $^{91}$.

Las expectativas y temores de la condesa se fueron despejando durante el primer año del reinado de Fernando VI, a la vez que se aclaraban las posiciones de los nuevos y los viejos ministros en la corte y se notaba el poder que lograba tener Carvajal, como ministro de Estado ${ }^{92}$. El nuevo monarca confirmó a Ensenada en sus cargos, pero como Huéscar dijo a Carvajal, no siempre el marqués gozó de la estimación de los "nuevos", es decir, el entorno de Carvajal y de los portugueses, que le veían demasiado apegado a la reina viuda. Ése era el temor de su clientela, y por ello, el de Margarita. En cuanto a la política exterior, el rey confirmó al propio Luis XV su intención de mantener la unión con Francia, pero también se ratificó en el pacto de buscar un establecimiento digno para el infante, el objetivo por el que se mantenía en la guerra de Sucesión Austriaca. El neutralismo que iba a caracterizar su reinado estaba aún por definirse y en él tuvo un protagonismo indiscutible el marqués de la Ensenada, que había logrado no sólo confirmarse en sus cargos sino también llegar al corazón de los monarcas y hacerles creer en su papel de pacíficos, pues el marques necesitaba la paz para comenzar sus proyectos, que el excesivo gasto militar obstaculizaba.

El nuevo binomio político que controlaba el gobierno intercedió para que Huéscar ocupara el cargo de Campoflorido como embajador de España en la corte gala. Así se demuestra en una carta de Margarita O’Brien: "y debo decir a V.E. que hace más de quince días, que él hubo decidido que vos debíais venir aquí, él me comunicó sus propósitos93". Fernando de Silva Álvarez de Toledo regresaba a la diplomacia con más poder y capacidad de acción y con mayor labor burocrática lo que su constitución enfermiza y su carácter indolente soportaron con dificultad ${ }^{94}$. En su nuevo puesto mantuvo su vinculación con la red ensenadista ya que necesitaba a la "farándula de don Zenón" para mantener el prestigio político y la confianza de los nuevos monarcas ${ }^{95}$. Además, continúo valiéndose de las agentes de Ensenada en Francia, de las que solicitó, expresamente, sus servicios: "La de Salas tiene buenas noticias y la O'Brien es cosa muy pre-

91. ADA, C. 204, no 5, Mme. O’Brien al duque de Huéscar, 18 de julio de 1746. En cifra.

92. GÓMEZ URDÁÑEZ, J.L., Fernando VI..., en especial, el capítulo titulado, "El fin del babel farnesiano", págs. 45-47.

93. ADA, C. 204, no 5, Mme. O’Brien al duque de Huéscar, 23 de agosto de 1746.

94. OZANAM, D, La diplomacia de Fernando VI. Correspondencia entre Carvajal y Huescar 1746-1749... págs. 70-76.

95. GÓMEZ URDÁÑEZ, J.L., El proyecto reformista de Ensenada..., pág. 77. 
cisa para nosotros. Dígaselo Vm. al Rey y que es menester que la socorra o con pensión buena o con sueldo decente, porque éste es un dinero muy bien gastado" ${ }^{\prime \prime 6}$.

\section{Guerra a la espera y Paz a la vista}

Margarita Isabel O’Brien, continúo en su papel de agente por expreso deseo del duque de Huéscar. En esta nueva etapa se reanudaron las visitas a su casa y el intercambio de correspondencia. Los ministros franceses trataron de aprovechar esta situación para ganarse al nuevo embajador. Prueba de ello es que Argensón no escatimaba en alabanzas por su nombramiento: "si el rey de España desea la unión sincera con el Rey de Francia ha de comenzar por quitar a Campoflorido" y añadía que "la persona más agradable para estar el Rey de España ante el Rey de Francia, por su mérito y probidad es el duque de Huéscar" ${ }^{\prime \prime 9}$. Sin embargo la información política que trasmitía la condesa de Lismore en sus misivas era un fiel reflejo de las desavenencias que seguían produciéndose entre ambas cortes. Así, Margarita hizo llegar a Ensenada el desacuerdo del marqués de Argenson y su cuñado Maillebois por la decisión del nuevo monarca de poner al marqués de la Mina al mando de las tropas galishispanas ${ }^{98}$. Las iniciativas militares eran vistas, cada vez más, como intentos velados de Francia de reducir su intervención a medidas paliativas que en ningún caso conseguirían un fin digno para el infante Felipe A ello había que unir la negativa de Francia al matrimonio del delfín con la infanta María Antonia, que Fernando VI tomó como una clara afrenta personal y dinástica ${ }^{99}$.

La espiral de recelo sobre los movimientos diplomáticos en ambas cortes aumentaba, hasta tal punto que, como Margarita O'Brien informaba a Ensenada, corroborando lo que el marqués ya sabía, había sospechas de que Francia estuviera iniciando conversaciones separadas y secretas con Inglaterra, y que en asegurando el reino de Nápoles, el resto de las pretensiones españolas, en especial Gibraltar -la espina, como la llama Carvajal-, quedaran al margen del futuro tratado (como así fue) ${ }^{100}$. En una de las cartas informaba: "El cardenal y el marqués de Argenson, me han di-

96. ADA, C. 202, no 11, Huéscar a Ensenada, 29 de agosto de 1746.

97. ADA, C. 204, no 5, Mme. O’Brien al duque de Huéscar, 23 de agosto de 1746.

98. Las cartas de la condesa de Lismore que tratan de forma monográfica la participación franco-española en el frente italiano son: ADA, C. 204, no 5, Mme. O’Brien al duque de Huéscar, 5 de septiembre de 1746, ADA, C. 204, no 5, Mme. O'Brien al duque de Huéscar, 12 de septiembre de 1746 y ADA, C. 204, no 5, Mme. O’Brien al duque de Huéscar, 23 de septiembre de 1746.

99. Las dimensiones políticas del cambio de reinado han sido expuestas de forma magistral en: GÓMEZ URDÁÑEZ, J.L., Fernando VI..., concretamente en el capítulo "Fernando VI, rey de España", págs. 45-63.

100. COXE, G., España bajo el reinado de la Casa de Borbón: desde 1700, hasta la muerte de Carlos III, acaecida en 1788, (Traducida al español con notas, observaciones y un apéndice por Jacinto de Salas Quiroga), Madrid, 1846-1847, tomo III, pág. 234. La obra ha sido recientemente reeditada en: España bajo el reinado de la Casa de Borbón: (1700-1788), (Estudio introductorio de Enrique Martínez Ruíz), Alicante, Universidad de Alicante, 2011. 
cho saber positivamente, que S.M. ha hecho su trato con Inglaterra, que ellos han visto como la más grande imprudencia que ha hecho Campoflorido, y lo último hecho de su mezquindad"101. Según este testimonio, la acusación iba de la mano del recién caído partido italiano, que no buscaba otro fin que desacreditar al nuevo gobierno "español" ante los ojos de Francia y fue considerada un caso grave de deslealtad. Ensenada sentenció al respecto: "pues si es verdad lo que madama O'Brien, Macanaz y otros avisan, son sus pecados de los muy graves y el despecho no los minora porque la fidelidad es primero que todo"102. Ensenada también hacia llegar, a través de la condesa de Lismore, las sospechas sobre las negociaciones secretas de Francia con Holanda. Unos temores que el cardenal de Tencin desmintió en una de las misivas:

Yo os doy mi palabra de honor, y sobre mi cabeza, y yendo al grano, le doy mi parte al duque de Huéscar, que S.M. y nosotros no haremos ningún trato ni emprenderemos ninguna negociación sin el visto bueno del rey de España, vamos a actuar vis a vis y no tendremos ni misterio, ni reserva para ello. Se le ha enviado el estado de la negociación con Holanda, (...) yo le juro que no hay nada más sobre la mesa ${ }^{103}$.

Las sospechas de ambas potencias se fueron confirmando y el papel de Francia en la política exterior española dejó de ser prioritario. El gobierno de Fernando VI centró sus estrategias en las negociaciones de Grimaldi en Austria y en las relaciones directas entre Carvajal y Keene sobre el viejo contencioso con Inglaterra, y a ellas se unieron las iniciativas de la reina para que Portugal mediara en las conferencias de Breda, donde un alocado Macanaz se labró su última desgracia $^{104}$. No obstante, conociendo el mundo de la intriga versallesca en que se mueve la política internacional en el siglo XVIII, era necesario estar al corriente de la posición de los ministros franceses y contar con varias fuentes, y por ello, Ensenada no prescindió de los servicios de la condesa de Lismore, a los que seguía considerando de gran utilidad, como demuestran estas palabras: "La O’Brien puede estar muy contenta y es cierto que V.m. hace de ella un uso muy útil"105.

Era "usada" por el embajador español, pero la condesa seguía sin olvidar la causa jacobita. Mientras el nuevo marco de las relaciones entre Francia y España iba definiéndose en dirección al próximo tratado de paz, el de Aquisgrán, los jacobitas intentaban mantener abierta la causa del "joven pretendiente". Carlos Eduardo Estuardo había Ilegado a Francia el 12 de septiembre de 1746 y a los

101. ADA, C. 204, no 5, Mme. O’Brien al duque de Huéscar, 15 de septiembre de 1746.

102. ADA, C. 202, no 12, Ensenada a Huéscar, 15 de septiembre de 1746.

103. ADA, C. 204, no 5, Mme. O’Brien al duque de Huéscar, 5 de septiembre de 1746.

104. OZANAM, D., La diplomacia de Fernando VI. Correspondencia entre Carvajal y Huescar 1746-1749..., págs. 14-17 y GÓMEZ URDÁÑ̃EZ, J.L., El proyecto reformista del marqués de la Ensenada..., págs. 58-63.

105. ADA, C. 202, no 12, Ensenada a Huéscar, 7 de septiembre de 1746. 
pocos días fue recibido por Luis XV con grandes honores y con numerosas muestras de afecto. Hay que destacar que a esto contribuyó que el episodio de su huída había alimentado la leyenda del "Prince in the Heather106", que despertaba curiosidad, admiración y simpatía, sobre todo entre las damas ${ }^{107}$. Ante este clima propicio, el rey frustrado y derrotado, reclamó su legitimidad como soberano de Inglaterra y demandó el apoyo de Francia. Apeló a los lazos de sangre que le unían a Luis XV, pues ambos descendían de Enrique IV108, y a la predilección que por él sentía la soberana francesa, la polaca María Lezinska, que aún conservaba el recuerdo de la buena amistad que mantuvo en su juventud con su madre, la princesa Sobiesky ${ }^{109}$. Según sus argumentos, con unos dieciocho o veinte mil hombres aliados contaría con la fuerza suficiente para recuperar el trono inglés invadiendo la isla. Como era de esperar, el rey francés y sus ministros hicieron oídos sordos y le respondieron con evasivas. Sólo el cardenal de Tencin le ofreció un proyecto de ayuda a cambio de que Irlanda pasara a Francia, pero Carlos Eduardo Estuardo, rechazó su oferta, pues, según él mismo manifestó había dedicado su vida a recuperar el trono inglés y no podía imaginarse su patria despedazada, antes prefería verla en manos de un Hannover ${ }^{110}$.

La llegada de Carlos Eduardo a Francia, con quien pronto se reunió su hermano Enrique, duque de York, hizo que la intercesión por la causa Estuardo cobrara un mayor protagonismo en la actividad de Margarita $\mathrm{O}^{\prime}$ Brien. Hay que tener presente que su marido formaba parte del séquito del "joven pretendiente", con lo que la dama tuvo un acceso directo a la actividad de los Estuardo en Francia. Una nueva situación que comunicó, inmediatamente a Huéscar y a Ensenada:

Yo adjunto una carta para S.E. el marqués de la Ensenada, la cual contiene el retorno heróico del príncipe Carlos Eduardo Estuardo, (...) Si me da a mí mismas órdenes, Mr. O’Brien estará en Fointeneblau en el séquito del príncipe, También V.E. podrá mandarme por mi marido las instrucciones ${ }^{111}$.

106. "Prince in the Heather" ("El príncipe en los brezos"): leyenda que circulaba en la Europa de mediados del siglo XVIII sobre la rocambolesca huída de Carlos Eduardo Estuardo a Francia, tras su derrota en la batalla de Culloden. Véase AMADEO PICHOT, M., Historia de Carlos Eduardo, último Príncipe de la Casa de Estuardo..., Vol. IV, págs. 113-125.

107. HOOK, M. y ROSS W., The Forty -Five. The last Jacobite Rebellion, Edimburgo, The National Library of Scotland, 1995, pág. 83.

108. AMADEO PICHOT, M., Historia de Carlos Eduardo, último Príncipe de la Casa de Estuardo..., Vol. IV, pág. 138.

109. LEVOUR, J., Madame Luis XV, la esposa del rey Bienamado, Madrid, Javier Vergara Editores, 1995, pág. 37.

110. CARPIO, M.J., España y los últimos Estuardos..., págs. 291-292.

111. ADA, C. 204, no 5, Mme. O’Brien al duque de Huéscar, 17 de octubre de 1746. 
El pretendiente Estuardo no tardó en demandar la mediación de la condesa de Lismore para ganarse el favor del embajador español, el duque de Huéscar, y de esta forma mejorar las relaciones diplomáticas con la Monarquía española, a la que consideraba una aliada tradicional. Una de las cartas de la condesa de Lismore recoge la invitación expresa de los príncipes a reunirse con Fernando de Silva Álvarez de Toledo y ganarlo para su causa. En esta invitación "el joven pretendiente" reconoció que su gesto llegaba tarde y mal, pues, ante el cálido recibimiento que le había dado el monarca francés, había descuidado el buen hacer diplomático con España:

Ellos me han encargado de tener el honor de mandarle, que nada da tanta pena como que se dude de ellos por vuestra parte, ya que independientemente de la consideración que ellos le deben como embajador del Rey nuestro principal; separan lo mismo ese carácter de V.E., por la que tienen una estima particular y semejante a la que les da, y no desean nada tanto como su amistad, que V.E. la tenga asegurada, y serán siempre sus amigos (...) Carlos Eduardo ha adjuntado, que él se acordaba que V.E. ha dicho que desea verle en particular, y que le ha respondido simplemente que será siempre con placer, y todas las veces que vos quiera, pero el príncipe ha adjuntado que es muy posible que no le hubiese entendido bien lo que V.E. le dijo, porque realmente una fluxión que él tiene dentro de la cabeza desde su vuelta a este país, le ha dejado un poco sordo.

Aquí está señor, palabra a palabra, lo que esos príncipes me han rogado que le mande, le aseguro que ellos serán de mucha ayuda, cuando los asuntos se lo permitan, de estar en el lugar donde ellos puedan tener el placer de verle y que es y será siempre un placer muy grande el que ellos tendrán ${ }^{112}$.

Se trata de la única carta en la que Margarita Isabel O'Brien sobrepasa su papel de intermediaria, para tratar de interceder a favor de los Estuardo, haciendo valer sus méritos ante el duque de Huéscar, como vuelve a reiterar en estas palabras:

...Para mí yo he caído de mi altura cuando sus príncipes me han dado esta comisión, no habiendo escuchado hablar hasta el descontento de V.E., y no imaginando que ella debía estar de acuerdo en algunos puntos de la parte de los príncipes, quienes tienen tanto manejo, vis a vis con nuestro principal, y al cual por otra parte os quiero en la creencia, tanto de estima para V.E. que por capricho de merecer su amistad, y de ser sus

112. ADA, C. 204, no 5, Mme. O’Brien al duque de Huéscar, 25 de octubre de 1746. Documento adjunto. 
amigos." (...) "Por Dios explíqueme para mí sola, que significa este asunto, pero yo creo poder asegurarle, que si ellos cometen error es sin su voluntad.

V.E. debe ver al príncipe Carlos Estuardo, como un héroe, un gran príncipe, un hombre perfectamente honesto, pero un verdadero montañés ${ }^{113}$.

Además de estos intentos de acercamiento entre los príncipes Estuardo y el embajador español, la condesa de Lismore, realizó gestiones a favor de los prisioneros jacobitas vinculados a la Monarquía española. Por una de sus cartas sabemos que intercedió por el señor Lelfus, irlandés de nacionalidad y ujier ordinario de la casa de Isabel de Farnesio, que había luchado junto con dos mil españoles, en el destacamento francés enviado a la batalla de Culloden ${ }^{114}$. La intercesión de la Monarquía española a través de la dama logró librarle de la pena de muerte con la que la justicia británica trataba de dar castigo ejemplar a los prisioneros jacobitas ${ }^{115}$.

\section{La paz de Aquisgrán y el fin de la misión}

La paz de Aquisgrán puso fin a un largo conflicto entre las potencias europeas cuyos orígenes se remontan hasta Utrech ${ }^{116}$. Las dos causas a las que sirvió la condesa, la española para quitarse la espina de Utrech y la jacobita para restaurar la derrotada dinastía católica en Inglaterra, entraban definitivamente en vías de solución con la firma del tratado. Carvajal lo aceptó a regañadientes; Ensenada, consciente de que era lo menos malo, la "guerra a la espera", como definió a la estrategia que debería adoptar España desde entonces, calló y dio comienzo a su proyecto de rearme. Para la agente jacobita y ensenadista, el tratado era un rotundo fracaso. Significaba el fin del idealismo irlandés y, el comienzo de sus dificultades en la corte francesa, en la que la paz se iba a gestionar de otra manera, ahora con el recelo de que los seguidores de Carvajal podían abandonar la Unión de las dos Coronas y aliarse a Inglaterra117.

El último servicio directo que realizó Margarita para la causa Estuardo fue informar del deseo del "joven pretendiente" de trasladarse a la corte española en

113. ADA, C. 204, no 5, Mme. O’Brien, 25 de octubre de 1746. Hay que precisar que la condesa de Lismore envió dos cartas el mismo día, tal y como figura en la data de las mismas.

114. ADA, C. 204, no 5, Mme. O’Brien al duque de Huéscar, 1 de octubre de 1746.

115. BLACK, J., Culloden and the '45.., pág. 134.

116. GÓMEZ URDÁÑEZ, J.L., "La estrategia político-militar en la España discreta: el ensenadismo", en: PÉREZ SARRIÓN, G. (Ed.), Mas Estado y más mercado. Absolutismo y economía en la España del siglo XVIII, Madrid, Silex, 2011, págs. 137-155.

117. GÓMEZ URDAÑEZ, J.L, "El Duque de Duras y el fin del Ministerio de Ensenada", en: Hispania: Revista española de historia, vol. 59, no 201, 1999, págs. 217-249. 
busca del apoyo que no había encontrado en Francia'118. A medida que pasaban los meses la posición del pretendiente en la corte francesa fue haciéndose más difícil, tornándose en abierta hostilidad cuando reaccionó con furia al enterarse de que ni Luis XV ni sus ministros iban a apoyar sus alocadas iniciativas de derrocar a la monarquía reinante en Inglaterra, lo que le llevó a abandonar Versalles y retirarse a Avignon con su corte ${ }^{119}$.

Ni la situación internacional de Francia ni la de España eran, en ningún caso, propicias, para aparecer en los foros internacionales auspiciando nada menos que un levantamiento contra Inglaterra, Carvajal quería la paz a ultranza y que Ensenada la negociaría en términos menos idealistas y más pragmáticos, reconociendo la posición de debilidad de las pretensiones de España ante Inglaterra, sin añadir nada relativo a los jacobitas, que se quedaron así sin valedores. Como diría el ensenadista marqués de la Mina, un trono para el infante era lo único que pondría fin a la guerra. ${ }^{120}$. En consecuencia la causa de los Estuardo, como le confesaría Carvajal a Huéscar: "era pura conversación"121, aunque también le manifestó cierto interés por la figura del "joven pretendiente": "cuando me escribas dime algo del príncipe Carlos Eduardo que tantas señas ha dado de un héroe completo al mundo"122. Al poco Carvajal tendría motivos que colmarían ese interés, pues Carlos Estuardo se presentó en Madrid.

Cegado en su empeño, el pretendiente llegó de improviso a la corte madrileña el 2 de marzo de 1747. A los tres días fue recibido por Fernando VI en audiencia secreta y, aunque se le colmó de halagos, se le dejó bien claro que España no daría apoyo militar a sus proyectos, rogándole "que se fuese luego porque no permitían otra cosa las circunstancias de los negocios públicos ${ }^{123 "}$. Carlos Estuardo insistió en sus propósitos recurriendo oficialmente al Ministro de Estado, Carvajal, que le volvió a invitar a que abandonara el país para evitar complicaciones diplomáticas. Sin embargo, su viaje a España no fue del todo infructuoso, pues el rey prometió mantenerle la pensión que por tanto tiempo le había pasado, en recompensa por su apoyo en la conquista de Nápoles; además le concedió una importante suma para sufragar los gastos de su viaje de regreso a Francia ${ }^{124}$.

118. OZANAM, D., La diplomacia de Fernando VI. Correspondencia entre Carvajal y Huescar 1746-1749..., pág. 147.

119. McKERRACHER, M., The Jacobite Dictionary..., pág. 15.

120. GÓMEZ URDÁÑ̃E, J.L., "Carvajal y Ensenada, un binomio político", en: Ministros de Fernando VI..., págs. 65-92.

121. OZANAM, D., La diplomacia de Fernando VI. Correspondencia entre Carvajal y Huescar 1746-1749..., pág 134.

122. Ibíd., pág. 106.

123. Ibíd., pág. 159, nota 1.

124. CARPIO, M.J., España y los últimos Estuardos..., pág. 235. 
Pero fue a su vuelta a París cuando "el joven pretendiente" sufrió la más dura de sus derrotas. Hubo de contemplar cómo las victorias de los generales franceses sobre el ejército inglés, en especial la del Mariscal de Saxe sobre el general Cumberland, no repercutieron en un renacer del apoyo francés a la causa jacobita, sino que, ante las voces de una paz, ya próxima, se zanjaba definitivamente el asunto haciendo pasar al olvido la última aventura romántica jacobita. El artículo quinto de la paz de Aquisgrán, firmada en octubre de 1748, reconocía la legitimidad indiscutible de los Hannover en el trono inglés y confirmaba la expulsión de Francia de Carlos Estuardo, que debería ir a Roma bajo la protección del Papa $^{125}$. Luis XV no solo lo aceptó sino que, ante la obstinación del "joven pretendiente", mandó que fuera capturado. Atado con "cordones de seda", se logró que abandonara por fin Francia. Acabó sus días en Roma, lamentando su destino y denunciando la traición de sus aliados ${ }^{126}$. Por su genio impetuoso y por la firmeza de sus ideales no asimiló nunca que su causa hubiese sido tratada como una simple pieza prescindible en el tablero internacional.

En el otro plano político en que se hallaba empleada la condesa, el servicio a España, la caída de Argenson precipitó el fin de la embajada extraordinaria de Huéscar, un año antes de la paz de Aquisgrán. La verdadera negociación estaba en Breda y luego en el propio Aquisgrán, donde Macanaz trabajaba en mil planes, algunos propios del hombre ingenuo y pasional que fue. La dama espía también perdió, por eso, su influencia, pero fue tan obstinada como el pretendiente Estuardo, pues siguió intercediendo por su causa ante los ministros franceses, a pesar de que ya no estaba bien visto. Sus maniobras en este terreno hicieron que dos años más tarde, entre enero y octubre de 1749, fuera también expulsada de Francia, pues se había ganado el odio de la corte, especialmente el del ministro Maurepas $^{127}$. El 14 de noviembre de 1749, el embajador francés en España, el marqués de Puyzileux, escribió a Margarita Isabel O’Brien “comunicándole la orden del Rey Supremo para que se prevenga y salga de París dentro de 4 días y se dirija a Orleáns hasta que S.M. ordene otra cosa"128. La condesa de Lismore se refugió en Labri e informó de su situación a Huéscar y a Ensenada, rogándo-

125. "El artículo 5ํํㄹ de la cuádruple alianza concluido en Londres el 2 de agosto de 1748, que contiene la garantía de la sucesión al reino de la Gran Bretaña en la casa de S.M. Británica actualmente reinante, y por el cual se previno todo lo que puede ser concerniente a la persona que ha tomado el título de rey de la Gran Bretaña y de sus descendientes de ambos sexos, se reproduce y se renueva expresamente por el presente artículo como si estuviese inserto en todo su contenido", en: CANTILLO, A., Tratados, convenios y declaraciones de paz..., pág. 319.

126. CARPIO, M.J., España y los últimos Estuardo..., pág. 295.

127. McKERRACHER, M., The Jacobite Dictionary..., 2007, pág. 176.

128. ADA, C. 204, no 5, Mme. O’Brien al duque de Huéscar, 15 de septiembre de 1749. En la carta, la condesa de Lismore adjunta la misiva en la que se le comunica su expulsión de Francia, que le fue transmitida por el embajador francés en España el marqués de Puyzileux. 
les que intercedieran por ella ante los monarcas españoles a fin de poder regresar a España:

Verá por la copia de la carta adjunta de Mr. Puyzileux cual es mi suerte; mi inocencia me ha conducido a refugiarme en Labri; protesto a S.E. por no haber hecho nada para reprocharme cara a cara en esta corte incluso con el más ligero propósito; el alejamiento del príncipe Eduardo; la forma en la que se lo ha tomado no me ha hecho actuar de otra forma; sino que S.M. instruida por exceso de desespero del que se supone que el príncipe estaba resuelto a llevar, ha creído su deber tomar todas las precauciones necesarias para evitarlas y su majestad fue por tanto informado de la prudencia de mis propósitos" (...) mi deber me llama cerca de la reina mi señora; no tengo otra patria y hago honor a España y toda mi ambición ha sido siempre irme a los pies de S.S.M.M., habitantes en los estados de S.M.C.; yo debo abandonarles porque él me lo ordena pero es del Rey (Fernando VI) de quien debo recibir las órdenes de presentarme den España donde V.E. va a tener una persona más que hará un deber y gloria de estar junto a V.E. y si yo dejo París antes de recibir las órdenes del rey y las vuestras ${ }^{129}$.

No obstante, antes de que se tomara una decisión sobre su destino por parte de la corte española, la francesa permitió su regreso a condición de que se dedicara, junto a su hijo Daniel James, a atender únicamente los asuntos de su marido. La condesa de Lismore desempeñó esta tarea hasta que el duque de York asumió la titularidad de la casa Estuardo. Por su desacuerdo con el carácter intrigante de la dama Enrique Benedicto Estuardo obligó a Margarita y a su hijo a desvincularse de la representación de la casa jacobita, bajo la amenaza de quitarles las pensiones ${ }^{130}$.

Fue entonces cuando Margarita O’Brien volvió los ojos hacia la corte española, sin otra posibilidad ${ }^{131}$. No hay que olvidar que su correspondencia con Ensenada y Huéscar se había mantenido, aunque sus misivas causaban cada vez más recelo y hastío y carecían de interés. Las cuestiones políticas anteriores a la paz perdieron protagonismo en favor de asuntos más domésticos, como muestran sus cartas, incluso las de 1747, referidas, únicamente, al sueldo de la dama o al aprovisionamiento de su casa ${ }^{132}$. En definitiva, la actividad diplomática cesó para esta mujer, pero los lazos clientelares así como su puesto y sueldo de dueña

129. ADA, C. 204, no 5, Mme. O’Brien al duque de Huéscar, 15 de septiembre de 1749.

130. McKERRACHER, M., The Jacobite Dictionary..., pag. 176 y OZANAM, D., La diplomacia de Fernando VI. Correspondencia entre Carvajal y Huescar 1746-1749..., pág. 86.

131 ADA, C. 204, no 5, Mme. O’Brien al duque de Huéscar, 4 de noviembre de 1747. Se trata de la única carta fechada en ese año y versa, únicamente, sobre el alquiler y aprovisionamiento de una casa para el duque de Húescar en la corte francesa.

132. AGP, Personal, Caja 749, expediente 9. 
de honor y el mantenimiento de las pensiones que había obtenido en esos años, que ascendían a unos 30.000 reales ${ }^{133}$, se mantuvieron. Además, su hijo fue incorporado a la armada española ${ }^{134}$, aumentando así el número de irlandeses, bajo la dirección de otro irlandés ${ }^{135}, \mathrm{O}^{\prime}$ Relly.

133. OZANAM, D., La diplomacia de Fernando VI. Correspondencia entre Carvajal y Huescar 1746-1749... pág. 106.

134. McKERRACHER, M., The Jacobite Dictionary..., pág. 176.

135. Un riguroso estudio sobre el papel de los irlandeses en el servicio militar de la Monarquía española en: Extranjeros en el ejército: Militares irlandeses en la sociedad española, 1580-1818, Madrid, 2007. 